\title{
Sex Trafficking Survivor, Pro-Life Advocate
}

Darlene Pawlik

Save The 1, gracefiles@comcast.net

Follow this and additional works at: https://digitalcommons.uri.edu/dignity

Part of the American Popular Culture Commons, Domestic and Intimate Partner Violence Commons, Family, Life Course, and Society Commons, Inequality and Stratification Commons, Nonfiction Commons, Politics and Social Change Commons, Psychology Commons, and the Women's Studies Commons

\section{Recommended Citation}

Pawlik, Darlene (2017) "Sex Trafficking Survivor, Pro-Life Advocate," Dignity: A Journal of Analysis of Exploitation and Violence: Vol. 2: Iss. 4, Article 8. https://doi.org/10.23860/dignity.2017.02.04.08

This Frontline Report is brought to you for free and open access by DigitalCommons@URI. It has been accepted for inclusion in Dignity: A Journal of Analysis of Exploitation and Violence by an authorized editor of DigitalCommons@URI. For more information, please contact digitalcommons-group@uri.edu. 


\title{
Sex Trafficking Survivor, Pro-Life Advocate
}

\author{
Abstract \\ I was conceived by rape. I was mentally, physically and sexually abused as a child. I endured four years of \\ juvenile sex trafficking. These experiences shaped my views on abortion and pro-life issues. Drawing from \\ my personal experience and the experiences of others, as well as referring to empirical evidence, I set \\ forth the position that children conceived through sexual violence are no less deserving of protection than \\ those conceived in loving relationships. Preserving the health and dignity of sexual abuse survivors is \\ important and supportive help is needed.

\section{Keywords} \\ abortion, rape, sex trafficking, child sexual abuse, survivor, pro-life \\ Creative Commons License \\ c) (i) $\odot$ \\ This work is licensed under a Creative Commons Attribution-Noncommercial-No Derivative Works 4.0 \\ License.

\section{Acknowledgements} \\ I would like to express my sincere gratitude to Dr. Donna Hughes for the opportunity and guidance \\ through this report, as well as Lisa Thompson, whose technical suggestions added clarity to the work. I'd \\ also like to thank Anthy Pallas and Marilyn Birnie for their heroic actions that made this possible. Rebecca \\ Kiessling for her assistance with this project. I'm grateful for all who are cited in this piece. Dignity thanks \\ the following people for their time and expertise in reviewing and editing: Lisa Thompson, vice president \\ for education and outreach, National Center on Sexual Exploitation, Tanya Street, human trafficking \\ survivor leader and founder of Identifiable Me, and Lily Lachapelle, University of Rhode Island double \\ major in psychology and gender and women's studies with a minor in Arabic.
}




\section{DIGNITY}

Volume 2, Issue 4, Article 8, 2017
A JOURNAL ON

SEXUAL EXPLOITATION

AND VIOLENCE

\title{
SEX TRAFFICKING SURVIVOR, PRO-LIFE ADVOCATE \\ Darlene Pawlik \\ Save the 1
}

\begin{abstract}
I was conceived by rape. I was mentally, physically and sexually abused as a child. I endured four years of juvenile sex trafficking. These experiences shaped my views on abortion and pro-life issues. Drawing from my personal experience and the experiences of others, as well as referring to empirical evidence, I set forth the position that children conceived through sexual violence are no less deserving of protection than those conceived in loving relationships. Preserving the health and dignity of sexual abuse survivors is important and supportive help is needed.
\end{abstract}

\section{KEYWORDS}

abortion, rape, sex trafficking, child sexual abuse, survivor, pro-life

I

was conceived by rape. I am a survivor of child sexual abuse and sex trafficking. I am also a pro-life advocate.

I sometimes encounter opposition to my pro-life beliefs in feminist circles. Feminists want to know how I could be pro-life, since I am a survivor of sexual abuse and sex trafficking.

I believe human life is of inestimable worth and value. Every woman, regardless of her political views or how she votes, no matter her religious affiliation, or other alliances should care about all sexual abuse and sex trafficking victims.

My mom was a 15-year-old virgin the first time he raped her. He told her he'd ruined her so she should marry him. When she realized she was pregnant with me, she acquiesced. She later explained to me that she felt she and I were in it together and having an abortion was not something she ever wanted to do. I realized that she saw me as a person.

She stayed with him for two brutal years. When she was pregnant again and on the verge of suicide, she disclosed to her mother her situation and left him to live with her. As my sister and I were growing up, we were subjected to my mother's severe outbursts of anger, and although she did take care of us, it was not tranquil.

My sister and I utilized opposite coping mechanisms as young children, which prompted my mother to give us unusual nicknames. My sister acted out. She sought attention constantly. She tripped, dropped and spilled things, talked incessantly, and cried. Her nickname was "Shut-up." 
In contrast to my sister, I was quiet. My strategy was to be unseen. I became numb. I shut down my emotions and I shut my mouth. I'd stand motionless, silently in the corner of a room, near or behind something that might obscure my presence. My nickname was "Sit-down."

Most abuse victims don't know they are victims. We just know that this is life. So, I never thought that I could raise my voice to stop what was happening. I'd been taught that silence would keep me from getting beatings.

Recently, my mother said she should have known that we were being abused. There were signs, such as nightmares, outbursts of anger, fighting, anxiety, and somatic symptoms. She knew he was a rapist. We should have been protected. We were too small to protect ourselves.

I believe protecting the vulnerable is what makes heroes. Remember the Miracle on the Hudson? The captain of USAir flight 1549 landed a plane on the river after the engines were destroyed. He was the last one off the plane, making sure all of his passengers were safe because he alone had the ability, the skills, and the responsibility to do so. He didn't try to figure out who was or was not worthy of risking his life. He protected all of the passengers. He is hailed as a hero because of it.

We couldn't protect ourselves as small children. Babies in the womb cannot protect themselves. They are the most vulnerable, and too small to protect themselves. My pro-life advocacy grew out of my own unmet need.

We all need heroes. I didn't have one until I reached adulthood.

When my mother divorced a second time, family and friends of the family were in and out of our apartment for days or weeks at a time. By then, I was old enough to stay home alone. We were not protected then, either. I refused to go to see my biological father's family, but it was a tumultuous time. A woman who stayed with us for a short time gave me a powerful combination of pills and booze. She molested me.

One of my mother's brothers molested me when I was 13. I managed to push him off of me before full intercourse. I ran and hid under my mom's bed. She woke up enough to tell my uncle to go back to sleep. It was common for people to stumble around in the middle of the night. Drugs and alcohol were ever present.

Because I didn't tell anyone about my uncle, he continued to physically and mentally abuse me. That was when my world seemed to completely spiral out of control. I was drinking and using any drugs I could get my hands on, stealing, and vandalizing. I lashed out at every turn, unable to process the emotions I had bottled up and tried to ignore for so long. I snuck out of the house in the quiet of the night. In tantrums of acting-out, I kicked out the windows at the bus stop. I tore open bags of shredded paper that were left on the sidewalk and littered the main street storefronts for blocks.

I skipped classes often and finally quit school in the sixth grade leaving me vulnerable to wolves in my neighborhood. An adult bodybuilder came around during the summer of my $13^{\text {th }}$ year and slowly groomed me to be sold to men for sex. The first time he sold me was to a businessman. On my $14^{\text {th }}$ birthday, I became a commodity. 
For four horrendous years, I suffered all kinds of deprivations, such as going without food for days, sleeping in the doorway of a church, and living outdoors in the New England winter without proper clothing.

I was used as an implement for the pleasure of men. I gagged and choked on one man after another in a car parked in the shadows of the alley outside a secret illegal gambling site. One of my mother's nicknames for me-"Fuck Face"-became all too real. I was beaten, gang-raped, drugged, dragged, and bruised in a sick game of dehumanization. My buyers were businessmen, city councilors, tradesmen, professionals, and criminals.

At 17, I was sold to one man to be his so-called "house pet." He didn't beat me, but he used me and degraded me verbally to keep me subjugated. The apartment I lived in was rented in the name of a candidate for sheriff, which of course further intimidated me. In graphic detail, he told me how he'd forced other girls to have an abortion, insisting I'd have to have an abortion if I got pregnant. I had been trafficked for years by then and hadn't gotten pregnant, so I didn't think I would.

When I did get pregnant, he said he would kill me if I tried to escape without having an abortion. He even threatened to do it himself. I didn't think I had anyone to turn to. I thought no one would listen to me. If I told people what was happening, I thought that I would be arrested and go to jail for speaking up. I had been arrested a few times before. So, in my mind I had no choice. To buy time, I made an appointment for an abortion with him breathing on my neck. I was terrified. Yet, I would rather have died than have an abortion.

I had a supernatural dream of an abortion from the perspective of the womb. I saw a little face, part of a hand with those distinct stubby fingers, and part of a ribcage. I say it was supernatural because I had no education, no way of knowing what it would look like at that time.

To save my baby and myself, I faked the abortion to get free from my trafficker. I told him I kept the appointment, but I didn't. Although I was terrified, I drew upon the emotions induced by the dream to find the strength to tell him that I wanted to leave. By some miracle, he let me go.

Even without a voice, preborn babies often deliver their moms from abusive situations.

I found my heroes: a social worker, who was assigned to track me when I was a runaway, and a woman who opened up her home to me when I was a hurt, homeless, pregnant teen. These two people opened the door for me to change my life forever. They valued my life and they valued my baby's life. Girls like me need real help to get through the trauma of sexual abuse.

Who benefits from a woman or girl having an abortion? Certainly, an abortion would have helped my perpetrator cover his crime. Abortion covers the abuse, destroying the evidence- the baby who could attest to the truth.

Coerced abortion is common in sexual abuse cases. My dear friend "Y" (2016) was 13 when her stepfather raped her, impregnated her, then took her for an abortion. He forced her to abort her first baby, which merely enabled him to continue raping her. None of the medical professionals involved asked her if she was safe. Within a year, she was pregnant again He took her for a second abortion, but her health had deteriorated after the first abortion, so she was too anemic to undergo 
the abortion. The clinic turned her away. Fortunately for her, she found the strength to get away from him and had her second baby.

Today, Y runs a pregnancy resource center. She founded the center to help girls and women in similar circumstances. She is treating them the way she should have been treated, offering real help for women and girls' needs. Y provides tangible supplies, support, and education.

K (2015) was conceived when her birthmother's father repeatedly raped his own daughter. He had forced multiple abortions on his daughter to keep the abuse from being found out. She managed to hide her pregnancy with K. long enough to deliver her. Ultimately, K's life was proof of the abuse.

I could go on with more stories, but simply, the baby is proof of the abuse. Tragically, many babies are aborted and their lifeless DNA reveals the rape. Even in their death, they deliver their mothers from continued sexual abuse.

In my case, I wanted so much for my baby to be protected, to be safe, and to have what I didn't have. So, I swore that if my unborn child was healthy, I would bring her up to know that there are good people in the world, to know God and the Bible. I knew that my life up to that point was a mess, but what was the solution?

Acknowledging the God-given dignity of every human being has been my life's focus ever since.

Along the way, I became friends with women who had experienced or survived an abortion or were pro-life activists. When I met victims of abortion, I knew I wanted to spare people from such a fate. I was drawn to pro-life activism. So, whatever I could do to spare women from the trauma of abortion, I did. In the beginning, I made a few phone calls to get people to pro-life educational events or to let legislators know that I opposed or supported bills that would affect the right to life. Then I took on more responsibilities. I have served as a pro-life advocate for more than half my life.

I am currently the Vice President of Save The 1, a global pro-life organization of nearly 500 people pregnant by rape or conceived by rape. I met the founder and president, Rebecca Kiessling through Facebook, when I posted a thank you to my mother on my birthday. Even people who claim to be pro-life won't stick up for us because we are commonly called "the exceptions" in pro-life discourse.

My sweet friend S (2016) was sexually abused by her own father and grandfather. She was removed from her family and placed in foster care, where she was raped by another youth and became pregnant. Then, while bonding with her unborn child, full of love, able to feel him kicking, she was taken by her foster mother to what she thought would be a checkup, but instead was taken for a forced abortion. S was devastated and spent many years without hope, without a voice, and without healing.

I have met many people with similar stories. There is a confused compassion which clouds common sense in cases of sexual abuse. People understandably want to fix the problem, but the baby isn't the problem. The problem is sexual abuse, and an abortion will never un-rape anyone. It does more harm by killing a child in a violent intrusion into a woman or girls' body. Two survivors of sexual assault (A and N) who submitted to abortion, have told me that, "The abortion was so much worse than the rape, much more destructive." 
Investigative journalist's reports have shown how abortion hurts women. Live Action has gone into abortion clinics with hidden cameras and documented how abortion vendors prey on juvenile sex trafficking victims, girls who have repeatedly been sexually abused. They have caught abortion clinic workers helping pimps figure out how to work the system to get abortions for girls as young as 14 without getting caught. They've told girls to lie about the age of the father, so the clinic wouldn't have to report it (Sexual Abuse Cover-Up, 2016).

Sex trafficking victims are already subjected to so much violence. A study by Lederer and Wetzel (2014) found that 55\% of the women survivors of sexual violence that they interviewed had one abortion and $30 \%$ of them had had multiple abortions.

Forced abortion is just one of the perils for victims, but it is especially damaging because it destroys the one person who can reveal the truth and help her escape. This is why I always tell people, saving my baby saved my life.

I attempted suicide a couple of times. I existed without regard for my own life, but upon learning of my baby's existence, I wanted to protect her. She gave me a reason to live beyond myself. She became my purpose for living, for eating well and making healthy decisions. I went to school and got a job. I focused all of my attention on making a life for us.

Post-abortive women experience trauma and develop many negative reactions related to the abortion, from suicide to murder and accidents to nightmares and post-traumatic stress disorder (PTSD). My personal observations after meeting so many sex trafficking survivors is that the forced abortions they suffered were tremendously damaging. For those who remain alive, every day is another wrought with coping strategies and constant effort to keep from swirling into despair. Depression, drug abuse, dissociation, self-destructive behaviors, and denial are common. Intrusive thoughts, avoidance, and anxiety disorders plague many (Psychological Effects of Abortion, n.d.). Forced abortion is common, adding to the sense of helplessness that sex trafficking victims face.

Abortion is an additional trauma to women who are pregnant as a result of sexual abuse and assault (Reardon, Makimaa \& Sobie, 2000). Dozens of women, who have published their stories on Save The 1, say that the abortion was far more devastating than the rape (Save The 1, 2014 \& 2016).

I talk to women at presentations and events across the country. When I share my experiences, invariably someone from the audience will disclose her own story to me. So many times, women tell me through their tears that loss and pain followed them for years. Abortion is a violent act that forces instruments into a woman's body for the singular purpose of destroying her child.

I believe the reason rape victims choose abortion $50 \%$ less often than other unplanned pregnancies (Holmes, Resnick, Kilpatrick \& Best, 1996) is because we know what it is to have our rights violated and we don't want to violate the baby's rights. We know it is the perpetrator that should be punished, not the baby.

A sense of justice has prompted me to speak out. The sexual abuse in my life silenced me. If telling people about my life and experience can help others avoid the same harm by speaking out, I will have fulfilled a purpose of immense value.

I have served as a board member, president, chair of the educational trust, and as chair of the political action committee for my state Right to Life organization for 
over 25 years. In all that time, no one was ever able to convince me that killing the innocent baby, who is a second victim of sexual violence, was a good thing.

If my mother had had an abortion, my death wouldn't have served justice. My daughter's death would have had no benefit to anyone. In no other circumstance do we condemn children for the crimes of their fathers. Neither of us deserved to have our lives taken away. In no other circumstances do we kill people because they might suffer. Life is hard and there are no guarantees of peace and happiness. I deserved to be protected. My daughter deserved to be protected. Every child, no matter how they were conceived deserves to be protected.

I am actively pro-life--especially because I was conceived by rape, especially after suffering sexual violence and especially after becoming pregnant as a result of juvenile sex trafficking.

Honoring the humanity of each person demands it.

Dignity demands it.

\section{ACKNOWLEDGMENTS}

I would like to express my sincere gratitude to Dr. Donna Hughes for the opportunity and guidance through this report, as well as Lisa Thompson, whose technical suggestions added clarity to the work. I'd also like to thank Anthy Pallas and Marilyn Birnie for their heroic actions that made this possible. Rebecca Kiessling for her assistance with this project. I'm grateful for all who are cited in this piece. Dignity thanks the following people for their time and expertise in reviewing and editing: Lisa Thompson, vice president for education and outreach, National Center on Sexual Exploitation, Tanya Street, human trafficking survivor leader and founder of Identifiable Me, and Lily Lachapelle, University of Rhode Island double major in psychology and gender and women's studies with a minor in Arabic.

\section{AUTHOR BIOGRAPHY}

Darlene Pawlik lives in New Hampshire, USA, with her husband of 27 years. She is a mother of five adult children and grandmother of two. She writes and speaks extensively on the subject of human dignity and the rights of personhood for the most marginalized and most vulnerable of all people, especially those conceived by sexual assault.

\section{RECOMMENDED CITATION}

Pawlik, Darlene. (2017). Sex trafficking survivor, pro-life advocate. Dignity: A Journal of Sexual Exploitation and Violence. Vol. 2, Issue 4, Article 8.

DOI:10.23860/dignity.2017.02.04.08. Available at

http://digitalcommons.uri.edu/dignity/vol2/iss4/8.

\section{REFERENCES}

A. (n.d.) Ashley Sigrest, Post Abortive from Rape. Retrieved from http://www.savethe1.com/ashley-sigrest-ms-pro-life-speaker/

Holmes, Resnick, Kilpatrick \& Best. (1996). Rape Related Pregnancy: estimates and descriptive characteristics from a national sample of women. US National Library of Medicine and National Institutes of Health. Retrieved from https://www.ncbi.nlm.nih.gov/pubmed/8765248 
K. (2015). Dave Sterrette, General Editor, We Choose Life. Chapter 12.

Lederer, Laura J. \& Wetzel, Christopher. (2014). Health Consequences of Sex Trafficking and Their Implications for Identifying Victims in Healthcare Facilities, Beazley Institute for Health and Policy, Annals of Health Law. Volume 23, Issue 1. Page 61. Retrieved from http://www.annalsofhealthlaw.com/annalsofhealthlaw/vol_23_issue_1?pg=69\# pg69

Psychological Effects of Abortion. (n.d.) Retrieved from http://abortionrisks.org/index.php?title=Psychological_Effects_of_Abortion

Reardon, Makimaa \& Sobie. (2000). Victims and Victors: Speaking Out About Their Pregnancies, Abortions, and Children Resulting From Sexual Assault edited by Reardon, Makimaa \& Sobie. p. 124-126 Retrieved from http://www.theunchoice.com/pdf/OnePageFactSheets/HardCasesSheet1.pdf

S. (2016). She conceived in rape at 13, but she was excited for a baby -then the worst happened. Retrieved from https://www.lifesitenews.com/opinion/sheconceived-in-rape-at-13-but-was-excited-for-a-baby-then-the-worst-happe

Save The 1 (September 9, 2014; January 14, 2016). Retrieved from http://savethe1.blogspot.com/2016/01/

Sexual Abuse Cover Up. (2016). Retrieved from https://www.liveaction.org/what-wedo/investigations/sexual-abuse-cover-up/

Y. (2016). My Son Is My Most Precious Treasure, Though Conceived From Step-Father Rape. Save The 1 Retrieved from http://savethe1.blogspot.com/2016/01/my-sonis-my-most-precious-treasure.html 